\title{
Využívání výukových případových studií při výuce environmentální ekonomie a politiky
}

Petr Šauer, Aleš Lisa

Envigogika 2007/II/2 - Recenzované články/ Reviewed Papers

Publikováno/Published 31. 08. 2007

DOI: http://dx.doi.org/10.14712/18023061.19

\section{Abstrakt:}

Každý univerzitní učitel by se čas od času měl zamyslet nejen nad tím, co učit, ale také jak to učit. Jednou z moderních metod výuky jsou tzv. výukové př́padové studie. Uplatnění nacházejí nejvíce $v$ aplikovaných společensko-vědních disciplínách, nejvíce tam, kde vyučovaná látka zahrnuje nějaké rozhodování lidí na různých pozicích.

\section{Klíčová slova:}

Případová studie, výuková př́ípadová studie

\section{Abstract:}

Teaching cases is quite well-known powerful educational tool, which belongs to modern methods of teaching and learning. They are distinguished from case studies used for research purposes.

\section{Key words:}

Case study, teaching case 


\section{Úvod}

Je třeba zdůraznit, že výukové př́padové studie se liší od běžných případových studií. Běžná př́padová studie představuje výzkumnou metodu. Zpravidla jde o shromáždění co možná detailní informace o zkoumaném praktickém prípadu, jeho detailní analýzu a odhalení príčinných souvislostí skutečností. Zpravidla se také od ní očekává formulace jednoho či více možných alternativních řešení daného problému, př́ipadně formulace dalšího postupu zkoumání.

Hlavním úkolem zpracování výukových případových studií není tolik dosažení nového poznání. Spíše má umožnit studentům př́ležitost naučit se co možná nejvíce o nějakém (zpravidla typickém) praktickém problému, naučit se samostatně hledat řešení tohoto problému a procvičit si na tom určité praktické dovednosti. Protože jde o výuku na vysokoškolské úrovni, významným cílem této metody výuky je procvičení si určitých metod, konceptů a/nebo teorií vyučovaných $v$ príslušné disciplíně, pro kterou jsou výukové př́padové studie připravovány, ale i využití poznatků z disciplín jiných.

Kvalitní výukové př́padové studie popisují reálnou situaci, poskytují potřebnou informaci $\mathrm{k}$ tomu, aby každý účastník si předem mohl promyslet řešení této situace a diskutovat ho při výuce. Hlavní rolí učitele potom je ř́idit tuto diskusi tak, aby prošla všechny významné body. Také průběžné hodnotí studenty podle toho, jak byli na diskusi připraveni.

Výukové případové studie nesporně patři mezi moderní formy výuky. Autoři tohoto článku a editoři připravované publikace výukových př́padových studií se setkali $\mathrm{s}$ jejich konkrétním uplatněním $v$ ekonomii, $v$ politických vědách a částečně i $v$ oblasti politiky životního prostředí. Osobně se účastnili pracovních seminářů $\mathrm{k}$ př́ípravě výukových prípadových studií, které také organizovali, mj. v rámci projektu Case Project for Central and Eastern Europe (1996).

Typické výukové př́padové studie $\mathrm{k}$ ekonomii Ize nalézt např́klad $\mathrm{v}$ publikaci Learning by the Case Method (Gomez-Ibanez; Kalt, 1990). Výukové prípadové studie $\mathrm{z}$ mnoha oborů potom například $\mathrm{v}$ katalozích známých pracovišt' $\mathrm{s}$ dlouholetou zkušeností s př́ípravou a výukou pomocí výukových prípadových studií. Za všechny zde zmiňme Case Program John F. Kennedy School of Government na Harvard University v USA (Case Program, 2007) a Cascade Center for Public Service na University of Washington v Seattlu v USA. Kromě vlastních výukových prípadových studií existují publikace k problematice jak výukové prípadové studie zpracovávat a podle nich učit (Boehrer, 1986; Gomez-Ibanez, 1986; Robyn, 1986; Garvin, 2006).

Příspěvek nejprve vysvětluje, co to výuka pomocí výukových případových studií jako jedna z moderních metod výuky je a jaké jsou hlavní rozdíly mezi běžnými př́padovými studiemi a výukovými prípadovými studiemi. Dále přináší informaci, jaké výukové př́ípadové studie byly vytvořeny v rámci projektu "Rozvoj kapacit VŠ pro udržitelný rozvoj"1, včetně toho, jak pokrývají spektrum metod, konceptů a teorií vyučovaných v rámci předmětu environmentální ekonomie a politiky a předmětu řešení environmentálních konfliktů vyjednáváním.

${ }^{1}$ Jde o projekt JPD3 č. CZ 04.3.07/3.1.01.1/0178. Projekt byl podpořen Evropským sociálním fondem, Státním rozpočtem České republiky a rozpočtem Hlavního města Prahy. 


\section{Výukové případové studie}

Aby student získal z výuky pomocí výukové prípadové studie maximum, neměl by vědět, jaká řešení jsou navrhována, případně ani jak byl př́pad $v$ praxi vyřešen. Dobrá výuková studie proto nesmí obsahovat řešení. Toto pravidlo platí jak pro reálné prípady, tak pro prípady hypotetické. Pokud v případu existují různé zájmy a postoje účastníkü, potom je nutné, aby výuková studie přinášela všechny hlavní postoje a náhledy vyváženě. Musí přinášet všechny podstatné informace o situaci $v$ přiměřeném rozsahu. Student musí dostat př́ležitost si udělat nezávislý obrázek o situaci a navrhnout a v diskuzi obhájit své řešení.

Obvyklé je diskutovat jednu prípadovou studii za týden během semestru a príprava může trvat jen přiměřenou dobu. Nelze tedy předpokládat, že student může prípadu věnovat stejný čas jako odborník, který se př́ipadem profesionálně zabývá. Obvyklý rozsah zadání jedné výukové studie je 10-50 stran, včetně prípadných př́loh. Dohledání dalších zdrojů informací, např́klad na internetu, Ize předpokládat, ale spíše již nad rámec běžné př́pravy. Nesmí se zapomínat, že jde o vysokoškolskou výuku a ne jen o běžné seznamování se s praxí. Cílem je, aby se student naučil aplikovat metody, koncepty a teorie, které zná. $\mathrm{K}$ tomu musí kvalitně připravená výuková studie přinášet podklady.

V neposlední řadě, výuková př́padová studie by měla být čtivá a srozumitelná. Může vzbudit zájem o určitý obor. Také je důležité si uvědomit, že ve studii jsou informace z různých oborů užívajících specifického jazyka a termínů. Tyto informace je třeba převést do podoby srozumitelné širšímu auditoriu. Pokud je to možné, na zpracování by se měl podílet kromě autora s hlubokou znalostí problému též kvalitní editor - „spisovatel". Vhodná je také kvalitní oponentura zadání výukové př́padové studie, zejména z hlediska obsahu všech podstatných a vyvážených informací.

Je tedy vidět, že běžná (výzkumná) případová studie a výuková případová studie se podstatně liší. K výzkumným př́íadovým studiím více viz např́klad Flyvbjerg (2006), Lamnek (2005) a Yin (2002). Hlavní rozdíly jsou stručně uvedeny v Tabulce 1.

Tabulka 1. Hlavní rozdíly mezi př́padovou studií a výukovou případovou studií.

\begin{tabular}{|c|c|c|}
\hline Charakteristika & Případová studie & Výuková případová studie \\
\hline Rozsah a míra detailů & $\begin{array}{l}\text { Může být velmi obsáhlá } \\
\text { a rozsáhlá }\end{array}$ & $\begin{array}{l}\text { Musí být přiměřeně } \\
\text { dlouhá, nemǔže } \\
\text { obsahovat př́liš detailů }\end{array}$ \\
\hline Řešení problémů & Musí být uvedeny & $\begin{array}{l}\text { Nesmí být ve studii } \\
\text { uvedeny (možná řešení } \\
\text { mohou být pouze součástí } \\
\text { poznámek pro učitele) }\end{array}$ \\
\hline Názorová vyváženost & $\begin{array}{l}\text { Může obsahovat alternativní } \\
\text { řešení, často však obsahuje } \\
\text { jen řešení výhodné pro } \\
\text { zpracovatele }\end{array}$ & $\begin{array}{l}\text { Musí přinášet } \\
\text { vybilancované informace } \\
\text { tak, aby student měl } \\
\text { možnost nalézt } \\
\text { alternativní řešení }\end{array}$ \\
\hline $\begin{array}{l}\text { Shoda popisované situace } \\
\text { s realitou }\end{array}$ & Musí řešit reálnou situaci & $\begin{array}{l}\text { Situace může být } \\
\text { částečně modifikována, } \\
\text { aby vystihovala typickou } \\
\text { situaci, př́padně aby } \\
\text { umožnila aplikaci určité } \\
\text { metody, konceptu či } \\
\text { teorie }\end{array}$ \\
\hline
\end{tabular}


Zpracovaná výuková případová studie může být využívána k podpoře běžných lekcí, tj. učitel ji může využívat k ilustraci přednášené látky a přicházet s (vlastními) řešeními, která jsou potom diskutována při hodině.

Avšak skutečná výuka pomocí výukové př́padové studie je zcela odlišná. Student musí mít text výukové studie k dispozici s dostatečným předstihem, aby se mohl na výuku kvalitně připravit. Ve studii mohou být explicitně formulovány otázky, ale mohou existovat studie, kde student musí objevit hlavní problémy a otázky sám a je podle toho také hodnocen. Všichni studenti musí být na výuku kvalitně připraveni. Role učitele již není cokoliv přednášet a vysvětlovat. Jeho úkolem je řídit diskuzi tak, aby během vyučovací hodiny (obvykle 90 minut) studenti prošli všechny významné problémy případu zachyceného ve studii a byla navržena a prodiskutována hlavní možná řešení. Přitom musí dát př́ležitost $\mathrm{k}$ diskuzi všem studentům a to i opakovaně. Př́spěvky studentů do diskuze tak musí být věcné, výstižně formulované a stručné. Učitel také musí studenty průběžně hodnotit. Zvláště v kreditním systému ECTS to může být problém, protože zde je třeba nejen rozhodnout o absolvování kurzu, ale také o známce. Na závěr kurzu mưže (ale nemusí) být součástí hodnocení i písemná práce či test. Výuka také vyžaduje vhodnou učebnu. Nemusí být nutně př́liš technicky vybavena, postačuje dostatečně velká tabule. Studenti by ale na sebe měli vzájemně vidět, nejvhodnější je "U" uspořádání. Studenti mohou mít na stolech viditelně svá jména, zejména tam, kde se vzájemně neznají.

\section{Metody, koncepty a teorie využitelné pro řešení výukových studií}

Při př́pravě výukových případových studií editoři a autoři nejprve sledovali metody, teorie a koncepty vyučované ve výše zmíněných kurzech týkajících se problematiky životního prostředí "v prvním plánu”. Patří sem zejména hodnocení a oceňování přírodních statků a oceňování ekonomických škod ze znehodnocování životního prostředí, environmentální etika, lidské environmentální potřeby, hodnoty a zájmy, environmentální právo, nástroje státní politiky životního prostředí, cesty řešení environmentálních problémů bez státní intervence, makroekonomické dopady znehodnocování a ochrany životního prostředí, vztahy environmentální politiky a dalších ekonomických politik a vzájemná integrace těchto politik, environmentální politika jako oblast prosazování zájmů a environmentální governance.

Dále byla sledována možnost uplatnění metod, konceptů a teorií z jiných disciplín, než je problematika životního prostředí. Zde byly uvažovány alternativní ekonomické teorie, cost-benefit analýza (veřejných) projektů, analýza nákladové efektivnosti (veřejných) projektů, metody analýzy efektivnosti soukromých projektů, matematické, statistické a ekonometrické metody a modelování, pravděpodobností uvažování, teorie veřejné volby a další.

\section{Praktické problémy obsažené ve studiích}

Výukové případové studie připravené v rámci zmiňovaného projektu pokrývají široké spektrum environmentálních problémů a rovněž vybrané problémy nakládání s přírodními zdroji. Problematika př́rodních zdrojů byla zahrnuta tam, kde existují rovněž nějaké souvislosti s problémy znehodnocování životního prostředí.

Není možné, aby relativně malý počet případových studií v rámci semestrálního předmětu pokryl všechny problémy, které jednotlivci i společnost musí v oblasti životního prostředí řešit. Přesto se editoři pokusili pokrýt problematiku všech hlavních složek životního prostředí a také ukázat problémy na místní, regionální, národní a mezinárodní úrovni. Řada z nich přináší informace o velmi kontroverzních veřejných a soukromých projektech. Jednotlivé výukové případové studie a problémy v nich obsažené Ize stručně charakterizovat následujícím způsobem: 
Voda

Eutrofizace povrchové vody $v$ České republice - Co je to eutrofizace a proč je to ekonomický problém? Jak je v České republice rozšířena? Jakými způsoby může být problém řešen? Jaká je zde role státní regulace a jaká dobrovolných přístupư?

Ochrana zdroje pitné vody před znečištěním - V 60. letech minulého století byla v Krušných horách postavena přehrada na pitnou vodu. Od 80. let docházelo ke zhoršování kvality této vody. Jaká je ekonomická stránka navrhovaných opatření? Kdo jsou hlavní političtí hráči $v$ př́ipadu? Jaké jsou jejich zájmy? Jak navržená opatření financovat?

Velké povodně $v$ České republice - Co je pravděpodobně příčinou vyššího výskytu povodní $v$ nedávné době? Jaké škody tyto povodně pưsobí? Které jsou hlavní subjekty, které by mohly učinit nějaká opatření? Jaká opatření jsou navrhována? Jaké jsou hlavní ekonomické a politické souvislosti v pozadí? Jaká je role veřejných autorit př̀ řešení?

Povodně ve vesnici Deštná - Ve dvou vesnicích poblíž česko-polské hranice dochází $v$ posledních letech $\mathrm{k}$ podstatně vyšší četnosti povodní. Příčinou je významné zvětšení povodí dvou místních potoků způsobeného mohutnými výsypkami hlušiny z dolu za hranicemi. Navržena jsou určitá technická opatření, jak riziko záplav sní̌it. Zjištěné ekonomické př́nosy projektů jsou však nízké. Je zde možnost, jak situaci řešit?

\section{Ovzduší}

Klimatická změna, kvalita ovzduší a energie: Příklad České republiky - Shrnutí argumentů pro pesimistické a optimistické pohledy na problém. Zdroje skleníkových plynů v České republice. Možná řešení a jejich ekonomické souvislosti. Ekologická daňová reforma a obchodovatelná práva na znečištění jako hlavní uvažované nástroje politiky životního prostředí v této oblasti.

Rekonstrukce a renovace teplárny $v$ podniku InUtil - Existuje několik variant, jak řešit $v$ podniku nový kotel na vytápění. Mají různé technické, ekologické a ekonomické parametry. Hlavní top-manažeři argumentují pro jednotlivé varianty. Jak vyřešit konflikt mezi nimi? Jaká je naděje na úspěch environmentální varianty řešení?

Politika parkování v Praze na Žižkově - Jaké jsou technické možnosti dosáhnout rovnováhy mezi nabídkou a poptávkou po parkovacích místech? Jaké jsou jejich ekonomické a politické souvislosti? Jaká je role municipality při řešení?

\section{Odpady}

Komunální odpady ve městě Kotěhůlky - nakládání s komunálním odpadem má svou dlouhou historii. Vstup do EU a nová česká legislativa přináší nové výzvy, jak problém komunálních odpadů řešit. Jaké jsou ekonomické souvislosti navržených řešení? Kdo jsou klíčoví hráči a jaké jsou jejich postoje k problému?

Nebezpečný odpad ve vesnici Rájov - Několik let nepoužívané budovy bývalého zemědělského družstva jsou využívány novým vlastníkem ke skládkování nebezpečného odpadu dováženého ze zahraničí. Jaké jsou etické a právní souvislosti situace? Jaké jsou role a možnosti municipality při řešení vzniklého problému?

\section{Př́ŕroda a krajina}

Rekonstrukce a revitalizace těžební oblasti pod Krušnými horami - Rozsáhlá povrchová těžba hnědého uhlí spolu $\mathrm{s}$ jeho spalováním v tepelných elektrárnách způsobily rozsáhlou devastaci krajiny. Jaké se nabízejí možnosti rekultivace? Jaké jsou jejich ekonomické a politické souvislosti? Jaké jsou možnosti financování navržených opatření?

Stavět či nestavět přehrady na Labi? - Plánuje se výstavba nového systému přehrad na Labi v blízkosti hranice $s$ Německem. Jsou prezentovány alternativní argumenty pro a proti projektu, včetně argumentů ekonomických. Mají se přehrady postavit? 
Ochrana ptáků a prírody na Kaprovsku - Konflikt mezi cíly v ochraně přírody a rybáři, zejména problém nadměrného rozšíření kormorána $v$ posledních letech. Jak problém řešit za současné legislativy?

Těžit či netěžit černé uhlí v Beskydách? - Do průzkumu ložiska kvalitního černého uhlí byly již investovány nemalé prostředky. Těžební společnost by chtěla zahájit těžbu. Ložisko se však nachází v chráněné krajinné oblasti. Jak situaci řešit?

\section{Energie a její environmentální souvislosti}

Výstavba nových zdrojů energie v České republice - Kolik energie země bude v budoucnu potřebovat? Jaké jsou možnosti úspor energie? Je atomová energie budoucností? Jaké jsou šance alternativních zdrojů energie?

Optimalizace spotřeby energie $v$ rodinných domech - Jaké zdroje energie se nabízí pro využití v rodinných domech? Jak minimalizovat spotřebu energie v rodinných domech? Jak minimalizovat negativní vlivy na životní prostředí u energie používané v rodinných domech? Jaká je role státu $v$ tomto problému?

Všechny výukové případové studie vycházejí z reálných situací. V některých př́padech editoři a autoři přistoupili $k$ menší modifikaci a změně názvů $z$ dưvodu důvěrnosti informací. Konkrétně jde o výukové prípadové studie Povodně ve vesnici Deštná, Rekonstrukce a renovace teplárny v podniku InUtil, Komunální odpady ve městě Kotěhůlky, Nebezpečný odpad ve vesnici Rájov a Ochrana ptáků a př́rody na Kaprovsku.

\section{Závěr}

Věříme, že připravené výukové studie, které systematicky pokrývají všechny významné metody, koncepty a teorie voblasti environmentální ekonomie a politiky a řešení environmentálních konfliktů vyjednáváním a rovněž vytvářejí prostor pro uplatnění teoretických i praktických poznatků z jiných oborù, mají potenciál zkvalitnit výuku v této oblasti. Témata obsažená ve výukových případových studiích zahrnují většinu nejčastěji diskutovaných praktických problémů významných pro Českou republiku. Jde o výběr z problémů regionálních, národních i mezinárodních dotýkajících se jedné země. K uváděným předmětům je zpracována e-learningová verze.

\section{Literatura}

- Boehrer, J. (1986). How to Teach a Case : Kennedy School of Government Case Program. Cambridge. Case, No, 18-95.

- Cantor, N. (1953). The Teaching-Learning Process. New York: Holt.

- Case Program (2007). Cambridge: Kennedy School of Government, Harvard University. Retrieved from http://www.ksgcase.harvard.edu

- Case Project for Central and Eastern Europe : Project Manual. Seattle (1996). : Cascade Center for Public Service, University of Washington.

- Šauer, P., \& Lisa, A. ed., . Environmentální ekonomie a politika: Výukové prípadové studie. .

- Flyvbjerg, B. (2006). Five Misunderstandings About Case Study Research. Qualitative Inquiry, 12(2), 
- Garvin, D. . Making the Case. Harvard Magazine, 2006. Retrieved from http://www.harvardmagazine.com/on-line/090322.html

- Gomez-Ibanez, J. A. (1986). Learning by the Case Method : Kennedy School of Government Case Program. Cambridge: Harvard University.

- Gomez-Ibanez, J. A., \& Kalt, J. P. (1990). Cases in Microeconomics. New Jersey: PrenticeHall.

- Lamnek, S. (2005). Qualitative Sozialforschung; Lehrbuch. 4. Auflage. Weihnhein, Basel: Beltz Verlag.

- MEB's Annotated Guide to Business and Environment Cases and Video (1995). Washington: Management Institute for Environment and Business.

- Robyn, D. (1986). What Makes a Good Case? : Kennedy School of Government Case Program. Cambridge: Harvard University.

- Yin, R. (2002). Case Study Research : Design and Methods. Applied social research method series. Volume 5. California. IndyPublish.com: Sage Publications.

\section{Recenzní posudky (slovní hodnocení příspěvku)}

\section{Recenzent 1:}

Nepřeje si zveřejnit své jméno ani text recenzního posudku. Připomínky recenzenta byly $v$ textu príspěvku zohledněny. Recenzent doporučil text př́spěvku k publikování.

\section{Recenzent 2:}

Nepřeje si zveřejnit své jméno ani text recenzního posudku. Recenzent doporučil text př́spěvku k publikování.

\section{Poznámky}

Tento článek vznikl $\mathrm{v}$ rámci projektu spolufinancovaného Evropským sociálním fondem, státním rozpočtem ČR a rozpočtem hl.m. Prahy. 
Časopis Envigogika vydává Centrum pro otázky životního prostředí UK. Vývoj časopisu je podpořen projektem OP VK Mezioborová sít udržitelného rozvoje.

Více najdete na internetových stránkách projektu mosur.czp.cuni.cz
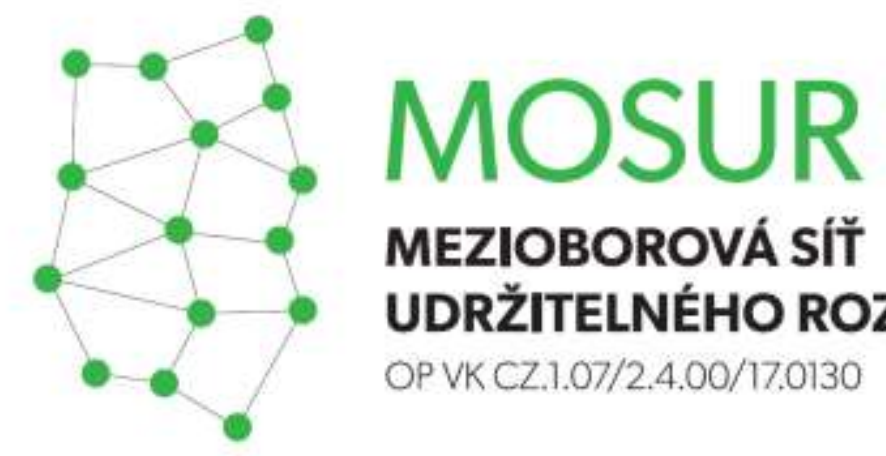

\section{MEZIOBOROVÁ SÍT} UDRŽITELNÉHO ROZVOJE

OP VK CZ.1.07/2.4.00/17.0130
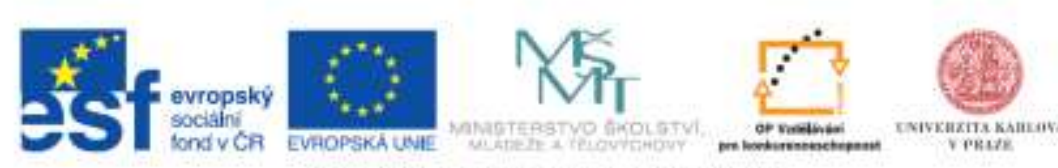

INVESTICE DO ROZVOUE VZDELAVANI 